\title{
Switching Costs and Customer Loyalty: A Review of literature
}

\author{
${ }^{1}$ Tawseef Ahmad Ganaie and ${ }^{2}$ Mushtaq Ahmad Bhat
}

${ }^{*}$ Research Scholar (Ph.D.) in Department of Commerce, University of Kashmir, Srinagar, 190006

2Professor in Department of Commerce, University of Kashmir, Srinagar, 190006

\begin{abstract}
Retaining customers in a competitive-value driven era is seen as a berculean task. Retaining customers for a longer time and reaping the benefit of customer lifetime value is seen as a major business activity that has a manifold influence on profitability, customer base, share of wallet, free word of mouth besides customer suggestions and feedback. In this direction, switching costs play an important role in influencing the customer loyalty. Switching cost acts as switching barrier which forces the customer to remain with the existing company and strengthens the customercompany longevity relationship. In view of the growing importance of switching costs and its influence on customer loyalty, this paper attempts to review switching costs and customer loyalty with a view to make switching costs barrier an effective tool to maintain a loyal customer base.
\end{abstract}

Keywords: Switching Costs; Switching Barriers, Customer Retention, and Customer Loyalty.

\section{Article Publication}

Published Online: 31-May-2021

\section{*Author's Correspondence}

8 Tawseef Ahmad Ganaie

8 Research Scholar (Ph.D.) in Department of Commerce, University of Kashmir, Srinagar, 190006

$\square$ tawseef.scholar@kashmiruniversity.net

C 2021The Authors. Published by

International Journal of Management and Development Studies

This is an open access article under the CC BY-NC-ND license (c)

(https://creativecommons.org/licenses/b y-nc-nd/4.0/)

\section{Introduction:}

The economic reforms along with rapid changes in technology expose the economy of a country to international competition. This paved the way for markets to maturity phase and led to the shift of domestic business to international competition. In a highly competitive market, acquiring new customers becomes difficult and retaining, maintaining, and satisfying existing customers is more challenging. Companies, therefore, have resorted to developing switching barriers to prevent customer defection. Previous research suggests that acquiring new customer is six times costly than maintaining and satisfying existing ones. In addition to this, as the customer-service provider relationship progresses, it deepens, subsequently, the customer loyalty increases and price sensitivity decreases (Rosenberg and Czepiel, 1984). It becomes imperative for the service provider to manage existing customer base to continue existing relationship for the greater good of the company. This is requisite to get the competitive advantage in the cut-throat competition for every service provider as the concept of quality services and customer satisfaction does not suffice to retain the customers in a competitive and innovative era (Kim et. al., 2020). It is, therefore, imperative for marketers to control the loss arising by customer defection and use switching barriers as a marketing strategy to reap the benefits of customer loyalty (Piha and Avlonitis, 2016), and enhance the operational profitability (Ranaweera and Prabhu, 2003).

The investigation of different types of consumer switching costs and its impact on customer loyalty not only strengthens typology and nomological network (Burnham, et. al., 2003; Gerbing and Anderson, 1988) but also provides the importance of switching barriers as a managerial tool to retain the customers and making them loyal to the company (Burnham et. al., 2003) as switching costs provides the organization an opportunity to satisfy the unsatisfied customers who are on the verge of defection (Valenzuela, 2012). 


\section{Objective of the Study:}

This paper is a humble attempt to explore the research carried out on the switching costs and customer loyalty. There are inconsistent results of switching costs on customer loyalty due to the application of wide measurements and classifications. An attempt, therefore, has been made to synthesize the classification of switching costs/barriers with a view to help marketers to maintain a loyal customer base.

\section{Methodology:}

This paper is purely descriptive and narrative. Initially, 90 papers were downloaded with keywords switching barriers, switching costs, customer retention, and customer loyalty which were searched out on the databases like, Emerald insight, Research Gate, Google Scholar, Taylor, and Francis, etc. Further processing of downloaded research papers restricted the number to 41 which acted as a reference for more than 30 papers. In total $41+30=71$ papers were used to meet our objectives. In addition, websites and reports have also been used for better comprehension.

\section{Literature Review:}

\section{Switching Costs}

Due to the ambiguity in the terminology of switching cost, different terms have been used interchangeably to represent the switching costs. Such as switching barriers, termination costs, and switching difficulties (Kim, et. al., 2020), which gives rise to single meaning to fundamentally different concepts (Klein and Delery, 2012). These different terminologies referring to the same concept may have created confusion among researchers and misinterpretation of the findings (McNulty and Brewster, 2017). Baloglu et. al., (2017) has mentioned that the "switching costs are the negative one type of switching barriers". This is not clear in the literature as to how these two terms are the same or different and both have a negative connotation. Jones, et. al., (2000) have defined switching barriers "any factor which makes it more difficult or costly for consumers to change providers". Porter, (1980) has defined switching costs as the one-time cost which the buyer has to sacrifice during switching from one supplier to another supplier. Clemes, et. al., (2010) has mentioned the switching costs as a "catch-all phrase" that is different kinds of costs that have to be sacrificed while switching service provider. Dissuading customers to switch to competitors' brand are generally known as switching cost (Caruana, 2003). It is simply the perception of the customer towards the magnitude of additional cost to end up the existing relationship and guarantee for an alternative one. These perceived costs discourage the customers to switch to the existing brand (Yanamandram and White, 2006), or switching costs are the direct costs that the consumer links with the process of changing the existing relationship with the new one (Burnham et. al., 2003). These costs impose a strain on the customers to continue the existing relationship even if they are dissatisfied because customers perceive the existing relationship more beneficial than switching (Pick and Eisend, 2014).

\section{Classification of Switching Costs}

According to Jackson (1985, cited in Ayden and Ozer, 2006), switching costs are the psychological, economic and physical costs which create an obstacle in the way of switching to alternative product or service. Switching costs can be monetary as well as non-monetary. Monetary switching costs are those which can be measured in terms of a currency unit, for example, special discounts, rebates, etc. and non-monetary switching costs are those which cannot be measured in terms of currency units, for example, the relationship and intimacy created during the progression of a relationship with the service provider. Klemperer (1987), identified three types of switching costs as learning cost, contractual or artificial cost, and transaction cost. He argued that switching cost seldom exists before the actual purchase by the customer. When the customer completes the transaction there appears the hidden cost which either the service provider has directly imposed or they are indirectly associated with the nature of the product or service. It may be referring to those products or services where customers have high involvement. He explained the transaction costs are those which the customer incurs when he preludes his relationship with the service provider or the cost when he terminates the existing relationship and switches to an alternative service provider. The perfect 
example of transaction cost can be found in the banking sector when the customer wants to open the same banking account with a competitor but he has to sacrifice high transaction cost on closing the banking account with the former. Learning costs are those costs where the customers have to put effort to get knowledge with the usage of the brand of an existing service provider and is not transferable to other brands of the competitor. The finest example of learning cost can also be found in the banking sector, when the customer intends to switch the bank, he has to acquire the knowledge about the service he is intending to buy from the bank. Artificial or contractual costs are those costs which service provider directly imposes on the customer in the form of coupons, discounts or rewards, service in a reduced price, etc. when the customer switches to alternate service provider he sacrifices these benefits.

Burnham, et. al., (2003), states that switching costs can be broadly classified into three groups as procedural switching cost, financial switching cost and relational switching cost. Procedural switching cost include economic risk, evaluation, learning and setup costs. Financial switching cost include quantifiable costs in terms monetary terms. Lastly, relational switching costs, those which cannot be measured in absolute terms. This includes brand relationship loss and breaking of the social bond.

Keaveney (1995) in his exploratory study presented switching barrier model in the context of the service sector. He classified switching cost into eight components as pricing (rates, charges, fees, service charges, surcharges, price deal and promotions, penalties and coupons, price increase); unfair practices; inconvenience (distant service providers' location, operation time and queuing time for service); core service failures (technical faults in the service like billing errors, mistakes, service catastrophes, etc.); service encounter failures (unfavorable attitude of employees or staff towards the customer); impoliteness (uncaring, unresponsive, unknowledgeable staff giving rise to the service encounter failure); attraction by competitors (feeling of competitor's product more utilitarian); ethical problems (those against the socially accepted norms like immoral and dishonest behavior, unethical practices, conflict of interests, intimidating behaviors or deceptive practices, etc.); employee response to service failure (fault in the service itself but is attributed to the failure on part of the employees who could not handle the situation effectively like failure to respond and not taking the customer's request or grievances seriously, and lastly, involuntarily switching cost (factors out of control for service provider or customer like the bank has moved its branch distant from the customers' working place, or the bank merged with another bank on which the customer has the least trust, etc.).

Guiltnan (1989) has broadly classified switching costs into four categories. They are contractual costs, setup costs, psychological commitment cost, and continuity costs. He defined contractual costs as the same as the Klemperer (1987)'s artificial/contractual cost. He merged transaction cost and learning cost into one group and named it 'set up cost'. In addition, he grouped the past expenditures or losses incurred and the time already consumed in building the existing relationship (sunk cost) into psychological commitment cost. Furthermore, the risk perception and the opportunity cost which arises from the switching from the known service provider to the unknown service provider.

Switching costs helps the service provider to retain the customer for a longer time and subsequently creating emotionally committed loyal customers, besides, switching cost is customer lifetime value which helps in making value-creating partners. Further, switching costs is the creation of 'Psychology of loss aversion' which don't let the customers switch to alternate service provider due to the aversion of losing economic benefit, customization services, and personal relationship. Previous research has suggested that humans feel more pain in losing than they feel the benefit of equal gain (Nuwire, 2018). Therefore, creation of perceived switching barrier makes people afraid of losing the existing benefits and become loyal to the existing service provider or brand. Lastly, switching costs itself acts as a loyalty program for the company to motivate, retain, and engage customers with an existing relationship.

Barroso and Picon (2012), has classified switching costs into three groups. They are customer-related switching costs, firm-related switching costs and industry related switching cost. He grouped habit, time, effort, commitment, psychological risk and expertise into customer-related switching costs, monetary, 
learning and search costs into firm-related costs and competition, service type and alternative attractiveness into industry related switching costs.

Blut, et. al., (2013) has classified the switching costs into internal (personal) costs and external costs. The ability to search based on prior knowledge, intelligence, and training is referred as personal or internal costs. This generally includes monetary and psychological efforts (Anderson and Sullivan 1993). External cost includes the opportunity cost of searching and monetary cost involves fetching the information. In addition to this, external costs are not under the control of the consumers.

\section{Customer Loyalty}

There is no universal consensus on the definition of customer loyalty. Oliver (1996), states customer loyalty as when customers patronize the products or services against all odds consistently despite situational influences and potential marketing tactics to switch to the competitor. Dick and Basu, (1994) states that customer loyalty is the association between the relative attitude of individual and repurchase, representing the sequence and probability of buying from the same seller. Oliver (1999) argues that to create a loyal customer is not a one-day task. It has to pass four stages viz. cognitive stage, in which customer relies on the information of the offerings. Customers buy the product if the cost-to-benefit ratio is in their favor else they search for better alternatives. To win the cognitive loyalty game, most service providers take a highly risky step to sell the product or service at loss for first-time customers. This increases their perception of cost-tobenefit-ratio and customers resort to repeating purchases to form affective loyalty. In affective loyalty, firms try to match the product or service characteristics with the expectations of the customer and the customers slightly start to prefer the product of an existing firm. In this stage the product or service purchased previously by the customer creates satisfaction. Affective loyalty is also related to creating affection with a customer through the use of memorable activities, say giving a free cup of coffee, advertising cards, and using notable logos. The affective form of loyalty gives rise to the conative loyalty in which a customer starts thinking of rebuying, again and again, the same brand. Blut, et. al., (2007), has attributed three features of conative loyalty, viz, willingness to recommend, cross buying intention, and repurchase intention. These intentions of the customer are turned into action loyalty, which means the customer repeatedly purchases the same product or service which reflects his social, financial, and individual liking. Customer become habitual or routinize buying with the same service provider. In short, customer loyalty is the commitment of the customer to use the product or service regardless of their prices and the alternative offerings of the competitors. In addition to this, fake news and rumors about the company do not affect loyal customers (Othman, et. al., 2020). The positive experience of loyal customers helps in spreading the word of mouth to a large stream of population and exhorts them to try the offerings. This helps the service providers to reduce the cost of attracting new customers besides achieving huge market share, financial stability and performance, and share of wallet (Arnott and Bridgewater, 2002).

\section{Switching costs and Customer Loyalty}

The switching costs/barrier is the strongest weapon in the globalized market to retain the customers, making friendly relations besides making the customers fearless, secure, trustworthy, and loyal (Eleni, et. al., 2017). Switching barriers have mixed results as these are the hurdles created by the service provider to retain the customers forcefully in the existing relationship and engage in repeat purchase. The dissatisfied customers prefer to be with the service provider if they perceive that switching costs him more than the existing benefits (Dick and Basu, 1994). In addition, there is ample scope on part of the service provider to attempt to persuade the dissatisfied customer to satisfy and make them loyal through the use of empathetic attitude, skill, and expertise of the frontline employees (Yanamandram, et. al., 2006). There is ample empirical evidence that the creation of switching barriers have mixed results on customer loyalty.

Many researchers (Augusto, 2009; Jalunder and Soderlund 2003; Ranaweera and Prabhu, 2003; David and Dagger, 2012) has found positive and significant impact of switching barriers on customer loyalty. The switching barriers have more weight on behavioral loyalty as compared to attitudinal loyalty (Emanuelsson 
and Skoglund, 2007). On the same lines, Lam, et. al., (2004) have found that switching barriers positively and significantly influences patronage and recommendation of the service to others. Some studies have affirmed the negative impact of switching barriers on customer loyalty (Colwell and Hogarth-Scott, 2004).These inconsistencies arise due to the two types of switching barriers viz. rewarding switching barriers and punitive switching barriers and also it depends upon the type of classification used by the researchers to obtain the results like attitudinal and behavioral loyalty (Aldaigan and Buttle, 2005; Valenzuela, 2012). The switching barriers which are rewarding in nature (organizational credibility, value congruency, and relational values) have a positive association with attitudinal and behavioral loyalty (Jalunder and Soderlund, 2003, Valenzuela, 2012). Those switching barriers that are punitive are negatively associated with customer loyalty (Valenzuela, 2012). In addition to this punitive switching barriers has a greater influence on behavioral loyalty as compared to attitudinal loyalty (Eleni, et. al., 2017). Furthermore, negative switching costs (monetary punishments, procedural steps) seem to make customers more determined to leave their banks and lower the effect of other good initiatives and reduces the chance of recovery action taken by the banks with these customers (Ngo and Pavelkova, 2017).

Previous research (Burnham, et. al., 2003) has found that punitive switching barriers have a positive impact on customer retention for a short time rather long time. Dick and Basu (1994), has found that few firms and industries globally develop switching costs to raise loyal customers. Benkenstein and stuhlreier (2004) have found that there is a positive correlation between service quality and customer retention and customers switch due to poor service quality in banks. Previous research (Reicheld and Sasser 1990) has also shown that the five percent reduction in customer defection increases profit by seventy-five percent and helps the firm to earn a competitive advantage in the market. Viard (2007) has argued that the relationship between switching cost and customer loyalty is relative and specific. Accordingly, increase in suppliers, gives rise to a decrease in demand, and the customers feel difficulty to switch from the existing one to alternative only because of the high switching costs and risk-aversion (Jackson 1985). Blut, et. al., (2007), has found that the switching barriers have a significant and positive effect on cognitive, affective, conative, and behavioral loyalty. These barriers strengthen the link between the four-stage loyalty model (Oliver 1997). Furthermore, Kaur, et. al., (2012) found that switching barriers, quick response to a service failure, reasonable prices, and core services up to the expectations significantly influences the switching intention, higher switching barriers lower the customer switching intention. On the same lines, Howshigan and Ragel (2018), have affirmed that there is a significant impact of switching barrier (switching cost and service recovery) on customer loyalty. Also, it was found that there is a negative significant relationship between the attractiveness of alternatives and customer loyalty. Ghouri, et. al., (2010) has investigated switching cost in terms of price, reputation, service quality, effective advertising competition, involuntary switching, distance, and switching cost and affirmed these factors significantly impacts switching behavior. In addition to it, they asserted price factor has a maximum weight on switching behavior of customers followed by switching cost, service quality, reputation, involuntary switching and effective advertising competition respectively. Furthermore, they found that if price increases by one unit, the probability of leaving existing service provider increases by $16.4 \%$. Othman, et. al., (2019), has investigated switching cost in terms of learning and search costs and affirmed significant impact of these on customer loyalty. Similarly, Ha, V. (2020) investigated switching cost in terms of learning cost, procedural cost and searching cost and concluded that these costs have significant impact on customer loyalty. He further asserted that switching cost increases 0.5 times customer loyalty. Koo, et. al., (2020), investigated switching costs related to loyalty program and attractiveness of alternatives on customer brand loyalty and concluded that switching costs influences customer loyalty significantly. Switching cost related to loyalty program has highest weight followed by attractiveness of alternatives on brand loyalty. Ngo, et. al., (2019) has investigated the switching cost in terms of positive switching cost (relational and financial switching cost) and negative switching cost (procedural switching cost) on customer loyalty and affirmed that both positive and negative switching has significant impact on creating loyal customers. 


\section{Conclusion and Managerial Implications:}

The above review of literature suggests that switching costs are those monetary and non-monetary costs that customers incur when they leave the existing relationship and the costs which they incur to begin new relationship with the new service provider. Switching barriers are those obstacles (monetary and nonmonetary) which acts like a barricade to the customer in leaving the existing relationship. To sum up, it means when the customer enters into the relationship with the firm by his choice it becomes the responsibility of the service provider to retain the customer by deploying optimum barriers to make him loyal. Furthermore, the existing literature have operationalized customer loyalty and customer retention with similar connotation which needs further concept clarity. We believe customer loyalty refers when the customer trusts, gets satisfied and whole-heartedly accepts the services of the provider and he makes his commitment to purchase the same services from the same provider despite change in competitor prices. Customer retention refers that the firm may be successful in retaining the customer but it does not guarantee the customer is internally satisfied with the service provider.

The purpose of switching costs or its managerial implication is to retain the customers with the existing relationship (Burnham, et. al., 2003) and, thereby, maintain a loyal customer base (Beerli, et. al., 2004). Switching costs are associated with the profitability or financial performance of the company (Burnham, et. al., 2003) and sustainable strategic advantage (Kerin, et. al., 1992). Switching cost or barriers may sometimes involve the loyalty benefit which the customer has to give up while ceding the relationship. These benefits which the customer had enjoyed may result in the recommendation of the service provider to the other customers (Lam, et. al., 2004). The barriers to exiting relationship motivates the customers to engage in repeat purchases (Stan, et. al., 2013; Jones, et. al., 2007) and increases affective and calculative commitment to remain with the existing relationship (Jones et. al., 2007).

In today's competitive market, customers are the king-pins of the market and have the freedom to choose the service of their choice. Service providers, therefore, have the opportunity to create the switching barriers through the process of value co-creation which future researchers need to investigate for better customer relationships.

\section{Reference}

Aldlaigan, A. and Buttle, F. (2005), "Beyond Satisfaction: Customers Attachment to Retail Banks", International Journal of Bank Marketing, 23(4), 349-359.

Anderson, Sullivan (1993), "The Antecedents and Consequences of Customer Satisfaction for Firms", Marketing Science, 12, 125-143.

Arnott, D. C., and Bridgewater, S. (2002), "Internet, Interaction and Implications for Marketing”, Marketing Intelligence and Planning, 20(2), 86-95.

Augusto de Matos, C., Luiz Henrique, J. and de Rosa, F. (2009), "The Different Roles of Switching Costs on the Satisfaction-Loyalty Relationship", International Journal of Bank Marketing, 27(7), 506-523. https://doi.org/10.1108/02652320911002331.

Aydin, S., and Özer, G. (2006), "How Switching Costs Affect Subscriber Loyalty in the Turkish Mobile Phone Market: An Exploratory Study", Journal of Targeting, Measurement and Analysis for Marketing, 14(2), 141155.

Baloglu, S., Zhong, Y. Y., and Tanford, S. (2017), "Casino Loyalty: The Influence of Loyalty Program, Switching Costs, and Trust", Journal of Hospitality and Tourism Research, 41(7), 846-868.

Barroso, C. and Picón, A. (2012), "Multi-dimensional Analysis of Perceived Switching Costs", Industrial Marketing Management, 41(3), 531 - 543.

Beerli, A., Martı 'n, J.D. and Quintana, A. (2004), "A Model of Customer Loyalty in the Retail Banking Market", European Journal of Marketing, 38 (1-2), 253-75.

Blut, M., Evanschitzky, H., Vogel, V., and Ahlert, D. (2007), "Switching Barriers in the Four-Stage Loyalty Model". ACR North American Advances, 726-734.

Blut M, Beatty SE, Evanschitzky H, Brock C (2013), "The Impact of Service Characteristics on the Switching Costs-Customer Loyalty Link", Journal of Retailing, 90, 275-290. 
Burnham, T. A., Frels, J. K., and Mahajan, V. (2003), "Consumer Switching Costs: A Typology, Antecedents, and Consequences", Journal of the Academy of Marketing Science, 31(2), 109126. https://doi.org/10.1177/0092070302250897.

Caruana, A. (2003), "The Impact of Switching Costs on Customer Loyalty: A Study among Corporate Customers of Mobile Telephony", Journal of Targeting, Measurement and Analysis for marketing, 12(3), 256-268.

Clemes, M., Gan, C. and Zhang, D. (2010), "Customer Switching Behavior in the Chinese Retail Banking Industry", International Journal of Bank Marketing, 28 (7), 519-546.

Colwell, S and Hogarth-Scott, S (2004), "The Effect of Cognitive Trust on Hostage Relationships"e, Journal of Services Marketing, 18(5), 384-394.

Dagger, T. S., and David, M. E. (2012), "Uncovering the Real Effect of Switching Costs on the Satisfaction-Loyalty Association", European Journal of Marketing, $46 \quad$ (3/4), 447468. https://doi.org/10.1108/03090561211202558

Dick, A.S. and Basu, K. (1994), "Customer Loyalty: Toward an Integrated Conceptual Framework", Journal Academy of Marketing Science, 22 (2), 99-113

Emmanuelsson, E. and Skoglund, V. 2007, "Virtual Switching Barriers: Switching Barriers and Customer Satisfaction as Predictors of Customer Loyalty for Online Retailersee, Essays, viewed 13 January 2009. http://www.essays.se/essay/b853ab9932.

Eleni Koutsothanassi, Nancy Bouranta, Evangelos Psomas, (2017), "Examining the Relationships among Service Features, Customer Loyalty and Switching Barriers in the Greek Banking Sector", International Journal of Quality and Service Sciences, $9(3 / 4), 425-440$.

Gerbing D, Anderson J. (1988), “An Updated Paradigm for Scale Development Incorporating Unidimensionality and its Assessment", J MarkRes, 43(3), 486-501.

Ghouri, A. M., Khan, N. U., Siddqui, U. A., Shaikh, A., and Alam, I. (2010), "Determinants Analysis of Customer Switching Behavior in Private Banking Sector of Pakistan", Interdisciplinary Journal of Contemporary Research in Business, 2(7), 96-110.

Guiltinan, J. P. (1989), "A Classification of Switching Costs with Implications for Relationship Marketing", In AMA Winter Educators' Conference: Marketing theory and practice, 216-20. Chicago: American Medical Association.

Ha, V. (2020), "The Effects of Attitude, Trust and Switching Cost on Loyalty in Commercial Banks in Ho Minh City", Accounting, 6(2), 151-160.

Howshigan, S., and Ragel, V. R. (2018), "The Effectiveness of Switching Barrier on Customer Loyalty Mediated with Customer Satisfaction: Telecommunication Industry, Batticaloa”, South Asian Journal of Social Studies and Economics, 1-9.

Jackson, B. B. (1985), "Build Customer Relationships That Last", Harvard Business Review, 11, 120-128.

Jones, M. A., Reynolds, K. E., Mothersbaugh, D. L., and Beatty, S. E. (2007), "The Positive and Negative Effects of Switching Costs on Relational Outcomes", Journal of Service Research, 9(4), 335-355.

Jones, M. A., Mothersbaugh, D. L., and Beatty, S. E. (2000), "Switching Barriers and Repurchase Intentions in Services, Journal of retailing", 76(2), 259-274.

Kaur et. al., (2012), "Exploring Customer Switching Intentions Through Marketing Paradigm", International Journal of Bank Marketing, 30(4), 2012, 280-302.

Keaveney, S. M. (1995), "Customer Switching Behavior in Service Industries: An Exploratory Study", Journal of Marketing, 59(2), 71-82. https://doi.org/10.1177/002224299505900206

Kerin, R.A., Varadarajan, P.R. and Peterson, R.A. (1992), "First-Mover Advantage: A Synthesis, Conceptual Framework, and Research Propositions", Journal of Marketing, 56 (October) 33-52.

Koo, B., Yu, J., and Han, H. (2020), "The Role of Loyalty Programs in Boosting Hotel Guest Loyalty: Impact of Switching Barriers", International Journal of Hospitality Management, 84, 102328.

Kim, K. A., Byon, K. K., and Choi, H. (2020), “A Conceptual Analysis of Switching Costs: Implications for Fitness Centers Sustainability", 12(9), 3891.

Klemperer, P. (1987), "Markets with Consumer Switching Costs", The Quarterly Journal of Economics, 102(2), 375-394.

Klein, H. J., and Delery, J. E. (2012), “Overview of the Special Issue”, Human Resource Management Review, 22, 57-61.

Lam, S.Y., Venkatesh, S., Erramilli, K.M. and Bvsan, M. (2004), "Customer Value, Satisfaction, Loyalty, and Switching Costs: An Illustration from A Business-to-Business Service Context", Journal of the Academy of Marketing Science, 32(3) 293-311.

McNulty, Y., and Brewster, C. (2017), "Theorizing the Meaning (s) of "Expatriate: Establishing Boundary Conditions for Business Expatriates", The International Journal of Human Resource Management, 28(1), 27-61.

Ngo, V. M., and Pavelková, D. (2017), "Moderating and Mediating Effects of Switching Costs on the Relationship between Service Value, Customer Satisfaction and Customer Loyalty: Investigation of Retail Banking in Vietnam”, Journal of International Studies, 10(1), 9-33, doi:10.14254/2071-8330.2017/10-1/1. 
Ngo, M. V., Phan, Q. P. T., Nguyen, N. V., and Vu, H. M. (2019), “The Mediating Effects of Switching Costs on the Relationship Between Service Quality, Customer Satisfaction and Customer Loyalty: A Study in Retail Banking Industry in Vietnam", International Journal of Supply Chain Management, ISSN: 2050-7399, pp. 389-393.

Nuwire. (2018, January 01), "The Benefits of High Switching Cost in E-Commerce", Retrieved from https://www.nuwireinvestor.com/benefits-high-switching-costs-ecommerce/.

Oliver, R. L. (1996), Satisfaction, “A Behavioral Perspective on the Consumer”, McGraw-Hill, New York, NY.

Oliver, R. L. (1997), Satisfaction, “A Behavioral Perspective on the Consumer”, McGraw-Hill, New York, NY.

Oliver R. L. (1999), "Whence Customer Loyalty?” Journal of Marketing, 63, Special Issue, pp. 33-44.

Othman, A. K., Hassan, L. F. A., Ibrahim, M. A. M., Saripin, M. S., Sapuan, N. S. A., and Roslan, Z. N. (2020), "Factors that Influence Customer Loyalty in Using E-Commerce", Journal of Islamic Management Studies, 2(2), 43-58.

Piha, L. P. and Avlonitis, G.J. (2015), "Customer Defection in Retail Banking: Attitudinal and Behavioural Consequences of Failed Service Quality ", Journal of Service Theory and Practice, 25 (3), $304-$ 326. https://doi.org/10.1108/JSTP-04-2014-0080

Pick, D., and Eisend, M. (2014), "Buyers' Perceived Switching Costs and Switching: a Meta-Analytic Assessment of Their Antecedents”, Journal of the Academy of Marketing Science, 42(2), 186-204.

Michael, E. P. (1980), “Competitive strategy: Techniques for Analyzing Industries and Competitors”, Editorial Free Pr, ISBN, 13, 9780029253601.

Ranaweera, C and Prabhu, J (2003), "The Influence of Satisfaction, Trust, and Switching Barriers on Customer Retention in a Continuous Purchasing Setting", International Journal of Service Industry Management, 14(3/4), 374-395.

Reicheld, F and Sasser, W (1990), "Zero Defections: Quality comes to services"e, Harvard Business Review, September-October, 105-111.

Rosenberg, L. J., and Czepiel, J. A. (1984), “A Marketing Approach for Customer Retention”, Journal of Consumer Marketing, 2, 45-51.

Söderlund, M. 2003, "The Retrospective and the Prospective Mind and the Temporal Framing of Satisfaction "e, European Journal of Marketing, 37 (10), 1375-1390.

Stan, V., Caemmerer, B., and Cattan-Jallet, R. (2013), "Customer Loyalty Development: The Role of Switching Costs", Journal of Applied Business Research (JABR), 29(5), 1541-1554.

Valenzuela, F. R. (2012), “The Effect of Switching Barriers Types on Customer Loyalty”, International Review of Business Research Papers, 8(1), 1-19.

Viard, V. B. (2007), "Do Switching Costs Make Markets More or Less Competitive? The Case of 800-Number Portability", The RAND Journal of Economics, 38(1), 146-163.

Yanamandram, V. and White, L. (2006), "Switching Barriers in Business-to-Business Services: A Qualitative Study", International Journal of Service Industry Management, 17 (2), 158-92.

Yavas, U., Benkenstein, M. and Stuhldreier, U. (2004), "Relationships between Service Quality and Behavioral Outcomes: A Study of Private Bank Customers in Germany", International Journal of Bank Marketing, 22(2), 144-157. https://doi.org/10.1108/02652320410521737. 